Precision Plus Protein Dual Color Standards, $500 \mu \mathrm{l} \# 1610374$

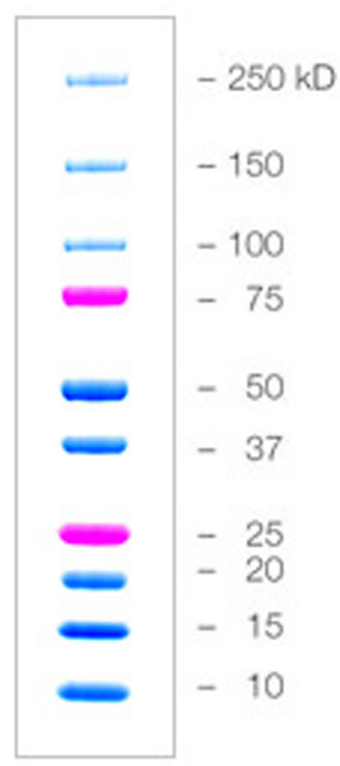

\title{
Claeved Caspase-3
} $17 \mathrm{kDa}$

\begin{tabular}{|r|c|c|ccc|ccc|}
\hline CGDCM $(\mu \mathrm{g} / \mathrm{ml})$ & - & - & 4 & 8 & 10 & 4 & 8 & 10 \\
$5-F U(\mu \mathrm{g} / \mathrm{ml})$ & - & 0.65 & - & - & - & 0.65 & 0.65 & 0.65 \\
\hline
\end{tabular}

cla

Claeved Caspase-3
$17 \mathrm{kDa}$

Actin 45 kDa

$\mathrm{Bcl}-225 \mathrm{kDa}$

Actin $45 \mathrm{kDa}$
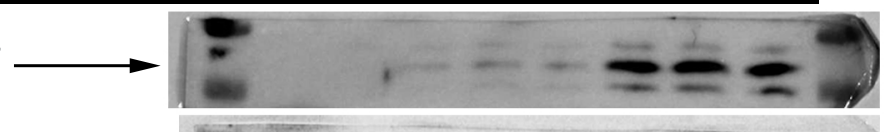

$20 \mathrm{kDa}$

$15 \mathrm{kDa}$

$50 \mathrm{kDa}$

$37 \mathrm{kDa}$

$25 \mathrm{kDa}$

$20 \mathrm{kDa}$

$50 \mathrm{kDa}$

$37 \mathrm{kDa}$

Actin 45 kDa

$\mathrm{Bcl}-225 \mathrm{kDa}$

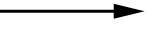

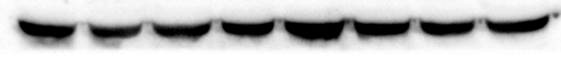

$37 \mathrm{kDa}$

$20 \mathrm{kDa}$

$15 \mathrm{kDa}$

$50 \mathrm{kDa}$

$37 \mathrm{kDa}$

$25 \mathrm{kDa}$

$20 \mathrm{kDa}$

Actin 45 kDa

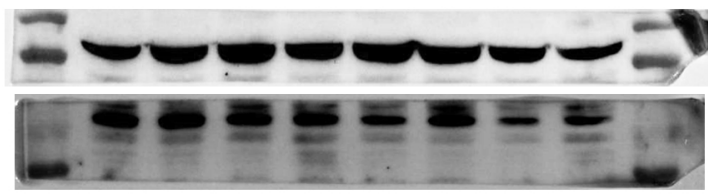

$50 \mathrm{kDa}$

$37 \mathrm{kDa}$

Claeved Caspase-3
$17 \mathrm{kDa}$

Actin 45 kDa
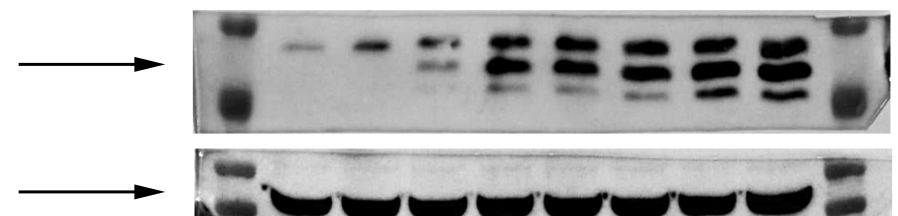

$20 \mathrm{kDa}$

$15 \mathrm{kDa}$

$50 \mathrm{kDa}$

$37 \mathrm{kDa}$

Bcl-2 25 kDa
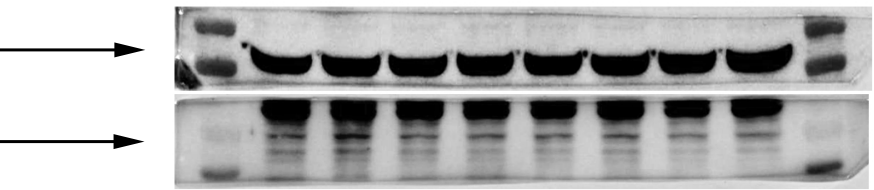

Actin 45 kDa

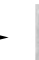

3 Corer

$20 \mathrm{kDa}$

$50 \mathrm{kDa}$

$37 \mathrm{kDa}$

$20 \mathrm{kDa}$

Claeved Caspase-3

$17 \mathrm{kDa}$

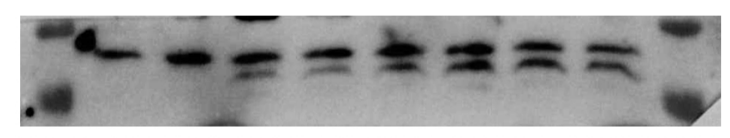

Actin 45 kDa

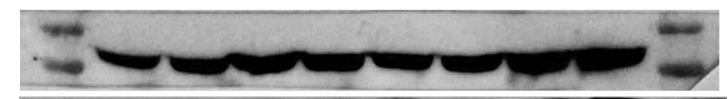

$15 \mathrm{kDa}$

$50 \mathrm{kDa}$

$37 \mathrm{kDa}$

Bcl-2 25 kDa

P

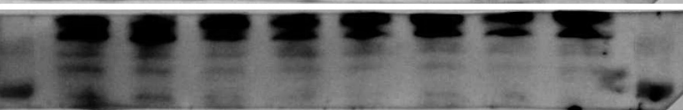

Actin 45 kDa

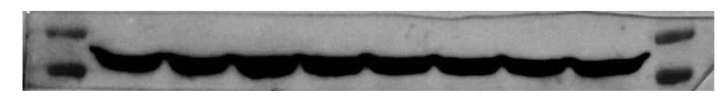

$25 \mathrm{kDa}$

$20 \mathrm{kDa}$

$50 \mathrm{kDa}$

$37 \mathrm{kDa}$

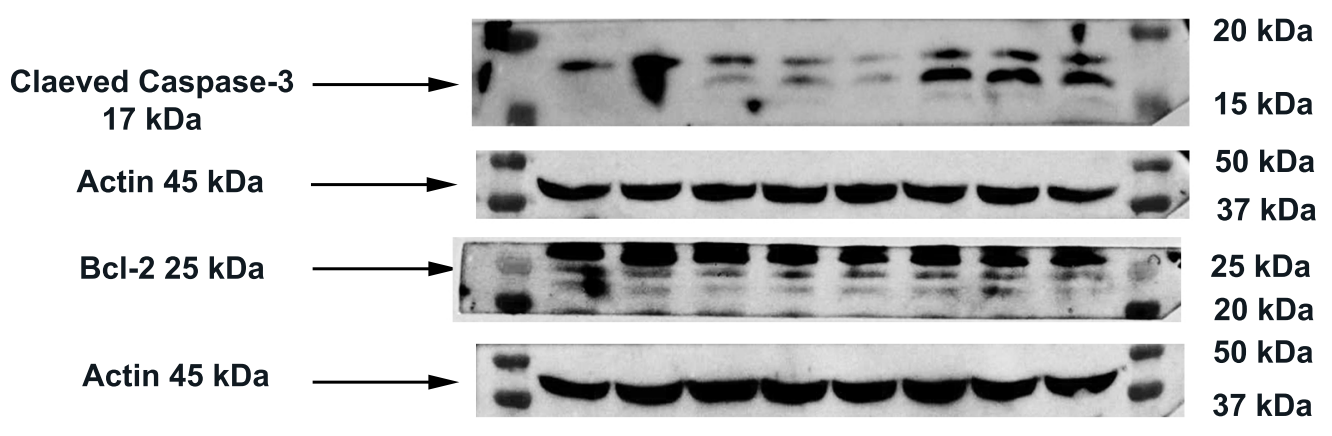

